\title{
QUESTIONNAIRE
}

Code............

Date.....................

The Burden of Malaria in Nkongho-Mbeng and Risk Factors Associated With the Disease Section one: Demography

1. Age.

2. Gender: (1) Male $\square$ (2) Female $\square$

3. Marital status: (1) Married $\square$ (2) Single $\square$ (3) Widow $\square$ (4) Widower

4. Village: (1) Dinte $\square$ (2) Mbetta $\square$ (3) Lekwe $\square$

5. Occupation: (1) Famer $\square$ (2) Teacher $\square$ (3) Health worker $\square$ (4) Business $\square$

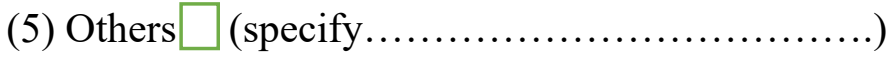

6. Educational level: (1) Never been to school $\square$ (2) Primary school $\square$ (3) Secondary school $\square$ (4) High school $\square$ (5) University and above $\square$

\section{Laboratory analysis}
1). Microscopy: (1) positive
(2) negative
2). Parasite load.

\section{Section Two: Social Status}

1. House type: (1) Mud block

(2) Cement block

(3) Others

$\square$ (specify

2. Number of people in the household:

3. Is there a ceiling?: (1)
(1) Yes
(2) No

4. If yes, type of ceiling: (1) Plywood

(2) Zinc

(3) Bamboo

(4) others (specify .).

5. Do windows have mosquito nets?:(1) Yes

(2) No

6. Is there space at the gable ends of the wall: (1) Yes

(2) $\mathrm{No} \square$ 
7. Type, type of toilet: (1) Pit latrine

(2) Water system

(3) Others

(specify (...................)

8. Do you often stay out of your home late into the nights: (1) Yes (2) No

9. What is your monthly income level:

\section{Section three: Malaria Management}

1. Have you ever had malaria: (1) Yes $\square$ (2) No $\square$

2. If yes, when did you last have malaria: (1) This month $\square$ (2) Five month ago

(3) One year ago

3. (a) Where do you take treatment for malaria: (1) Health center (2) Drug store $\square$ (3)Herbalist (4) Automedication (5)Others (specify..... .)

(b) Which drug did you use: (1) Athermeter $\square$ (2) Quinine $\square$ (3) Don't know $\square$ (4) Others $\square$ (specify...............)

\section{Section four: Vector control}

1. Is there standing water within 20 meters around the house: (1) Yes (2) No

2. Are there bushes around the house: (1) Yes (2) $\mathrm{No}$

3. Are there crops around the house:

(1) Yes (2) No

4. If yes, what type: (1) Plantain (2) Cocoa (3) Coffee (4) Cocoyam (5) Others (specify

5. Do you have a mosquito net?: (1) Yes (2) No

6. If yes, how frequent do you use it: (1) everyday (2)Some days (3) Don't use

7. What is the state of the net: (1) Old (2) Fairly use (3) New

8. Dose the net have holes: (1) Yes (2) No

9. Have you ever seen a dead insect on your net:(1) Yes (2) No 
10. Have you ever seen a dead mosquito on your net: (1) Yes $\square$ (2) No $\square$

11. Where did you obtain the net: (1) Market $\square$ (2) Health center $\square$ (3) Campaign $\square$

12. When did you obtain the net: (1) A month ago

(2) 6 months ago

(3) 1 year ago

(4) Others $\square$ (specify.................)

13. Do you use insecticide mosquito spray: (1) Yes

(2) No

14. If yes, how frequent do you use it: (1) everyday

(2) Some days

(3) Don't use

15. Where do you carry your drinking water: (1) Spring

(2) Stream

(3) River

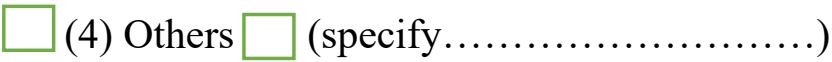

16. How do you store water in the house: (1) Open containers

(2) Close containers

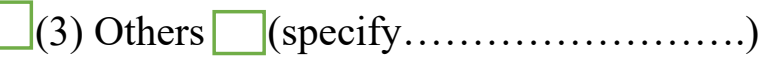

\section{Thank you for your time}

